\title{
The Adoption of the Declaration of the Principles on the Grand Ethiopian Renaissance Dam and Lessons for South Asia
}

\author{
Surya Nath Upadhyay and Prakash Gaudel
}

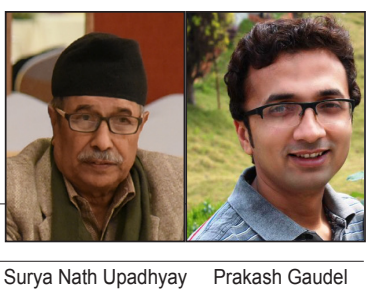

Abstract: This paper discusses how an upper riparian country can establish its water right of fulfilling own water needs through development of a transboundary river in a contested terrain of water management. Citing the case of the development of Grand Ethiopian Renaissance Dam (GERD) and adoption of the Declaration of the Principles by the Eastern Nile Basin States, this paper highlights the major lessons that South Asia need to learn to achieve water security in the region through cooperation. This paper further argues that if, economically weak upstream riparian country, Ethiopia can initiate such an important and strategic project, then Nepal must also be in similar position to fulfill own demand without causing significant harm, rather benefiting the downstream countries. Like Egypt and Sudan, the lower riparian countries Bangladesh and more importantly India need to be in a position to acknowledge the downstream benefit principle. This paper states that without cooperation among riparian states of the Ganges basin, the sustainable development of the region seems limited.

Keywords: Transboundary River, riparian states, downstream benefit principle, co-operation

\section{Background}

Surging population, growing economies and changing Nclimatic patterns have resulted in increased pressures on the existing water resources all over the world. This has resulted in the increased concerns over sharing of transboundary waters as well. Since the history of water development, economically and geopolitically strong states have predominantly received the major chunk of benefits from the transboundary waters. The changing global context and the thrust for development in the remaining co-riparian states have initiated them to claim their equitable share of water and benefits from these transboundary waters. Thus, the international (transboundary) rivers are coming under growing pressure from increasing water demand and water quality deterioration (Sadoff and Grey, 2002). This has, in many cases, resulted into conflicts while in other cases the riparian states have moved from conflict to cooperation. This paper deals with a recent case of development of such cooperation on transboundary waters of the Nile from Africa and focuses on the lessons the remaining world can learn.

\section{The Nile Basin: Colonial Past to Cooperative Present}

The Nile River, the longest river of the world, is the lifeline for its basin countries since the ancient times. In today's world, the river crosses political boundaries of 11 countries. The Nile River system originates from two distinct geographical zones as there are two main tributaries - the White Nile and the Blue Nile. The Blue Nile originates from Lake Tana in the Ethiopian Highlands. The White Nile originates from the springs of Burundi and Rwanda. These springs combine to form the Kagera River, which flows into Lake Victoria. The Lake Victoria which is shared by Tanzania, Uganda and Kenya is the main source of White Nile. From the Lake, the White Nile flows through Lakes Kyoga and
Albert, and thereafter enters the Republic of South Sudan (Salman, 2013). The White Nile meets Blue Nile at Khartum, the capital of Sudan. The Nile then flows through Lake Nasser and the Aswan Dam before splitting into major distributaries at Nile Delta which flow into the Mediterranean Sea.

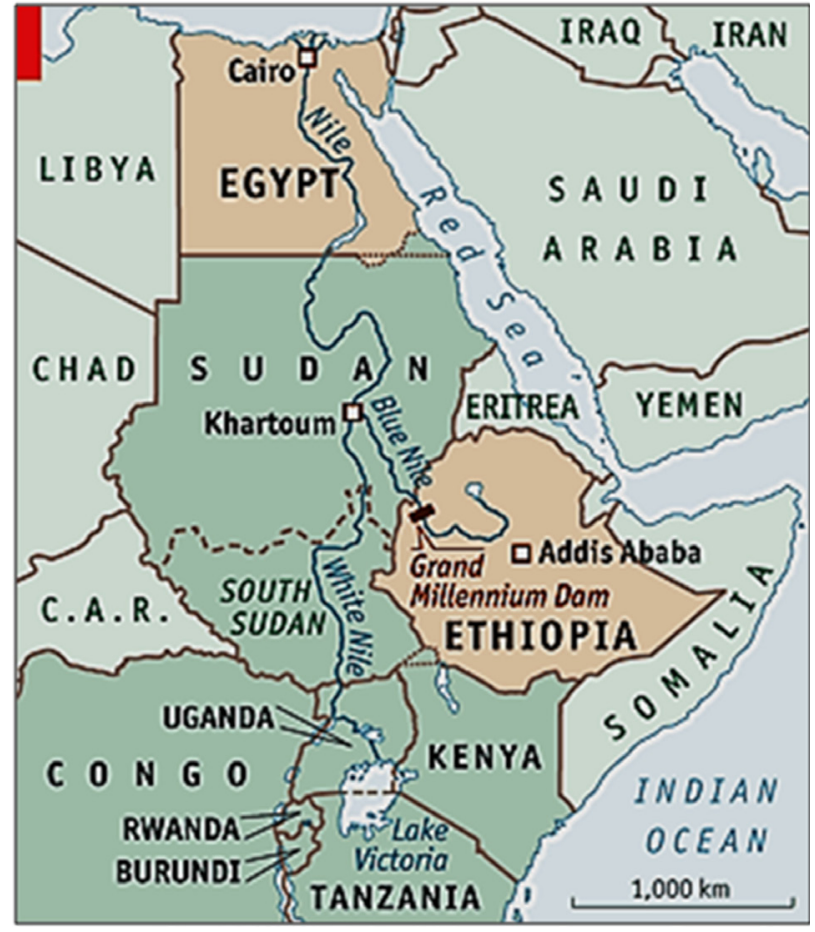

Figure 1: Nile Basin States

(Source:http://venturesafrica.com/wp-content/ uploads/2013/06/Nile-dam.gif)

The life of about 300 million people is dependent on Nile water and by 2030 the figure is expected to reach 500 million (Salman, 2013). Agriculture is the main consumptive water use sector in the Nile Basin as $78 \%$ 
of the peak flow at Aswan is consumed by agriculture. Without Nile, it is hard to imagine the survival of these people. It is, therefore, important to analyze the issues of conflict and cooperation related to Nile water. The following sections deal with such issues in relation to the Nile basin development. water is high mainly because of its arid climate. As the annual rainfall in Egypt is reported to be zero, except in Cairo which annual rainfall may reach $25 \mathrm{~mm}$ and that of the Mediterranean coast may reach 200mm, such climate does not support rain-fed agricultural activities (Deng, 2007). Nevertheless the 1959 Nile Waters Treaty between Egypt and Sudan, allocated well over 95\% of

\begin{tabular}{|c|c|c|c|c|}
\hline $\begin{array}{l}\text { S. } \\
\text { No. }\end{array}$ & $\begin{array}{l}\text { Date and } \\
\text { Place of } \\
\text { Signing }\end{array}$ & Name of Agreement & Signing Parties & Remarks \\
\hline 1. & $\begin{array}{l}1902 \\
\text { (May 15) } \\
\text { Adis } \\
\text { Ababa, } \\
\text { Ethiopia }\end{array}$ & $\begin{array}{c}\text { Treaties between UK } \\
\text { and Ethiopia, and } \\
\text { between UK, Italy and } \\
\text { Ethiopia, relative to } \\
\text { the Frontiers between } \\
\text { Sudan, Ethiopia and } \\
\text { Eritrea. }\end{array}$ & $\begin{array}{l}\text { UK, Ethiopia } \\
\text { UK, Italy and } \\
\text { Ethiopia. }\end{array}$ & $\begin{array}{l}\text { Ratifi- } \\
\text { cation } \\
\text { delivered } \\
\text { at Adis } \\
\text { Ababa on } \\
\text { October } \\
28,1902 .\end{array}$ \\
\hline 2. & $\begin{array}{l}1929 \\
\text { (May 7) } \\
\text { Cairo, } \\
\text { Egypt }\end{array}$ & $\begin{array}{c}\text { Exchange of Notes } \\
\text { in regard to the use } \\
\text { of the waters of the } \\
\text { River Nile for Irrigation } \\
\text { purposes. }\end{array}$ & UK and Egypt & \\
\hline 3. & $\begin{array}{c}1953 \\
\text { (Jan. 5) } \\
\text { Cairo, } \\
\text { Egypt }\end{array}$ & $\begin{array}{c}\text { Exchange of Notes re- } \\
\text { garding the construc- } \\
\text { tion of the Owen Falls } \\
\text { Dam in Uganda }\end{array}$ & $\begin{array}{c}\text { UK of Great Brit- } \\
\text { ain and Northern } \\
\text { Ireland and } \\
\text { Egypt }\end{array}$ & \\
\hline 4. & $\begin{array}{l}1959 \\
\text { (Nov. 8) } \\
\text { Cairo, } \\
\text { Egypt } \\
\end{array}$ & $\begin{array}{c}\text { Agreement for the Full } \\
\text { Utilization of the Nile } \\
\text { Waters }\end{array}$ & $\begin{array}{c}\text { United Arab } \\
\text { Republic (Egypt) } \\
\text { and Sudan }\end{array}$ & $\begin{array}{c}\text { in force } \\
\text { on De- } \\
\text { cember } \\
12,1959 \\
\end{array}$ \\
\hline 5. & $\begin{array}{l}2010 \\
\text { (May 14) } \\
\text { Entebbe, } \\
\text { Uganda }\end{array}$ & $\begin{array}{c}\text { Nile Cooperative } \\
\text { Framework Agreement } \\
\text { (Entebbe Agreement) }\end{array}$ & $\begin{array}{c}\text { Ethiopia, Tanza- } \\
\text { nia, Uganda and } \\
\text { Rwanda (later } \\
\text { on signed by } \\
\text { Kenya on May } \\
\text { 19, } 2010 \text { and } \\
\text { Burundi on Feb } \\
28,2011 \text { ) } \\
\end{array}$ & \\
\hline 6. & $\begin{array}{c}2015 \\
\text { (March } \\
23) \\
\text { Khartoum, } \\
\text { Sudan }\end{array}$ & $\begin{array}{l}\text { Declaration of the } \\
\text { Principles On the } \\
\text { Grand Ethiopian Re- } \\
\text { naissance Dam Project }\end{array}$ & $\begin{array}{c}\text { Ethiopia, Sudan } \\
\text { and Egypt }\end{array}$ & \\
\hline
\end{tabular}

Table 1: Agreements related to Nile Water

\section{Basin Development and Conflicts}

The history of the sharing of Nile water is marked by political and economic processes rather than equity and justice (Upadhyay, 2012). Egypt and Sudan are the largest water consumers while this is negligible for Ethiopia, even though $85 \%$ of the Nile waters come from Ethiopian highlands (Mulat and Moges, 2014). The vast irrigation systems in Egypt and to a lesser extent Sudan are wholly dependent on Nile water, whereas Ethiopia has developed less than five per cent of the irrigable land in the basin. The dependency of the Egypt on Nile the estimated available Nile waters to Egypt and Sudan thereby leaving very little to the other nine states in the basin. Prior to 1959 , a number of agreements have been made, which has rather increased tension among the riparian states. But some agreements made recently have attempted to help improving the situation.

\section{The Bilateral and Multilateral Agreements}

The Nile River has witnessed different agreements between and among the riparian states during the last two centuries. Between 1891 and 1925, during the colonial period, the United Kingdom (UK) entered into five agreements with different States of Nile Basin on the utilization of the Nile waters (OkothOwiro, 2004). These agreements were done in the colonial era, and the riparian states had very little to decide on their own water resources. The following table shows chronological order of different agreements on Nile water.

Most of these earlier treaties were done in colonial era. The Nile Treaty of 1902 is considered as the major source of disputes between Ethiopia and the downstream states of Egypt and Sudan. Salman (2013) has critically examined the Treaty and argued that Article III of the Treaty, which restricts Ethiopia to construct structures or develop Blue Nile and other water bodies that disturbs the water flow in the Nile downstream, is the main cause of such dispute. On the contrary, Ethiopia is of the opinion that as the Treaty was not ratified by any of the government body and done in the colonial era, the Treaty, at present, is no more acceptable. Whereas, Egypt insists that the Treaty is still valid and binding on Ethiopia as a successor to the Treaty. Hence, the tension persists.

With regard to using transboundary water of Nile, an Agreement was signed on May 7, 1929 between Egypt and Britain with Britain acting on behalf of Sudan. The purpose of the 1929 Nile Agreement was to guarantee and facilitate an increase in the volume of water reaching Egypt (Okoth-Owiro, 2004). Paragraph 4(ii) of the Agreement restricts any irrigation or hydropower generation activity on the Nile or its tributaries located in Sudan or in countries under British administration 
which could jeopardize the interests of Egypt either by reducing the quantity of water flowing into Egypt or appreciably changing the date of its flow or causing its level to drop. Deng (2007) argues that the 1929 Agreement produced three cardinal legal principles, which Egypt has since been invoking in case of disputes with other riparian states over the Nile waters: the principle of established rights; the notion of equitable shares; and rights of construction beyond territorial boundaries. This has, thus, unfairly empowered and authorized Egypt to undertake reconstruction projects beyond its geographical and political domain.

The 1953 Agreement was signed between Egypt and Britain (on behalf of Uganda). This agreement allowed Egypt to control and regulate water in the Nile from outside its territory, with the construction of the Owen Falls Dam. With this Agreement, Egypt agreed on sharing the cost of dam necessary for raising the level of Lake Victoria for storage purpose. Egypt further agreed to pay the sum of $£ 980,000$ to Uganda Electricity Board as a compensation for consequential loss of hydro-power and inundation due to rise in water level in the Lake.

After three decades, in the year 1959, the 1929 Nile Agreement was revised by an independent Sudan and Egypt. The Agreement again ignored upstream states including the independent Ethiopia. Aswan High Dam in Egypt and Roseiris Dam on the Blue Nile in Sudan were constructed under this Agreement. A Permanent Joint Technical Committee, with an equal number of members from each country, as the institutional mechanism for the joint management of the Nile was established under the Agreement (Salman, 2013). These treaties signed over almost a century ago awarded only Egypt and to some extent Sudan, the major share of Nile water. This is the reason why Egypt claims historical rights to the Nile waters and thus does not expect any interruption of its flow by the upper riparian countries (Deng, 2007).

\section{The Basin Institution}

The Nile Basin Initiative (NBI) was established on February 22, 1999 with the shared vision to achieve sustainable socio-economic development through equitable utilization of and benefits from the common Nile Basin water resources. This institution is an intergovernmental partnership for cooperative management of the Nile Basin. The NBI was set up by nine Nile Basin states (Burundi, Congo, Egypt, Ethiopia, Kenya, Rwanda, Sudan, Tanzania and Uganda), with Eritrea as an observer. Mohamed and Loulseged (2008) consider NBI as a remarkable achievement towards the cooperative development and management of the common Nile water resources. The NBI has designed and provided a negotiation forum for 'Cooperative Framework Agreement (CFA)' which is expected to solve several organizational issues as it shall transform the work of transitional NBI into permanent Nile River basin Commission (NBC) which shall provide equal access to the Nile's water and potential for development (McKenzie, 2012). The NBI has not secured yet any nod from Egypt although it is now increasingly very difficult for Egypt to establish its historical rights in the face of other riparians joining hands.

\section{The Grand Ethiopian Renaissance Dam (GERD)} The GERD, formerly known as the Millennium Dam and being constructed on Blue Nile (Figure 1), would be the largest hydroelectric dam in Africa with gross storage of 74.01 BCM (Billion Cubic Meters) and live storage of 59.22 BCM. With installed capacity of $6000 \mathrm{MW}$, this hydro-project has the capacity of producing 15,692 GWh of electricity annually (IPoE, 2013). This energy is roughly 50\% more than average hydropower generation from Aswan High Dam over the past four decades. The construction works mainly include a Roller Compacted Concrete (RCC) gravity dam (main dam with crest length of $1780 \mathrm{~m}$ and height of $145 \mathrm{~m}$ ), a rock-fill saddle dam (crest length $4800 \mathrm{~m}$ and height of $45 \mathrm{~m}$ ), two surface powerhouses and a gated spillway. At Full Supply Level (FSL) of 640masl, the reservoir will cover an area of $1,874 \mathrm{~km}^{2}$ (IPoE, 2013). This under-construction project on the Blue Nile lies in Ethiopia. The project is owned by Ethiopian Electric Power Corporation (EEPCo), a public utility enterprise.

\section{The History of Conceiving the Project}

The US Bureau of Reclamation carried out a Blue Nile survey in between 1956 and 1964 which identified the eventual site for GERD. After a half century, the Government of Ethiopia re-surveyed the site in October 2009 and August 2010 and made it public on March 31, 2011. The project was formally launched on April 2, 2011 by the Ethiopian Prime Minister which started the construction of the project. The project is presented as mainly being intended for generating hydroelectricity which is much needed for the region. Out of 16 Francisturbine generators, each of $375 \mathrm{MW}$, the first two generators are expected to become operational after 44 months of construction.

\section{The Rise of Disputes}

The dispute over Nile has lasted almost for a century, since the colonial periods. Egypt and to a lesser extent Sudan were major beneficiaries of the Nile water uses from 1929 and 1959 Agreements, whereas the remaining upstream states have limited access. In such circumstances, the opening of the GERD, a major dam project in the upstream country Ethiopia, helped to coerce the disputes. The main dispute was related to the existing consumptive use of water and water right of the downstream states of Egypt and Sudan.

\section{The Mode of Financing}

The total construction cost of the project is 4.2 billion 
USD (Schadomsky, 2013). Ethiopia started building the dam on its own since the multilaterals did not participate because of the objection of other countries particularly Sudan and Egypt. So, the government of Ethiopia has been insisting that, this big dam can be built without financial aid from abroad, though it has accepted credit from China of more than one billion USD for the transmission lines. The project is partly financed by deductions to salaries of the state employees. This means that the Ethiopian people are thus making substantial scarifies to implement this project from the domestic financing sources.

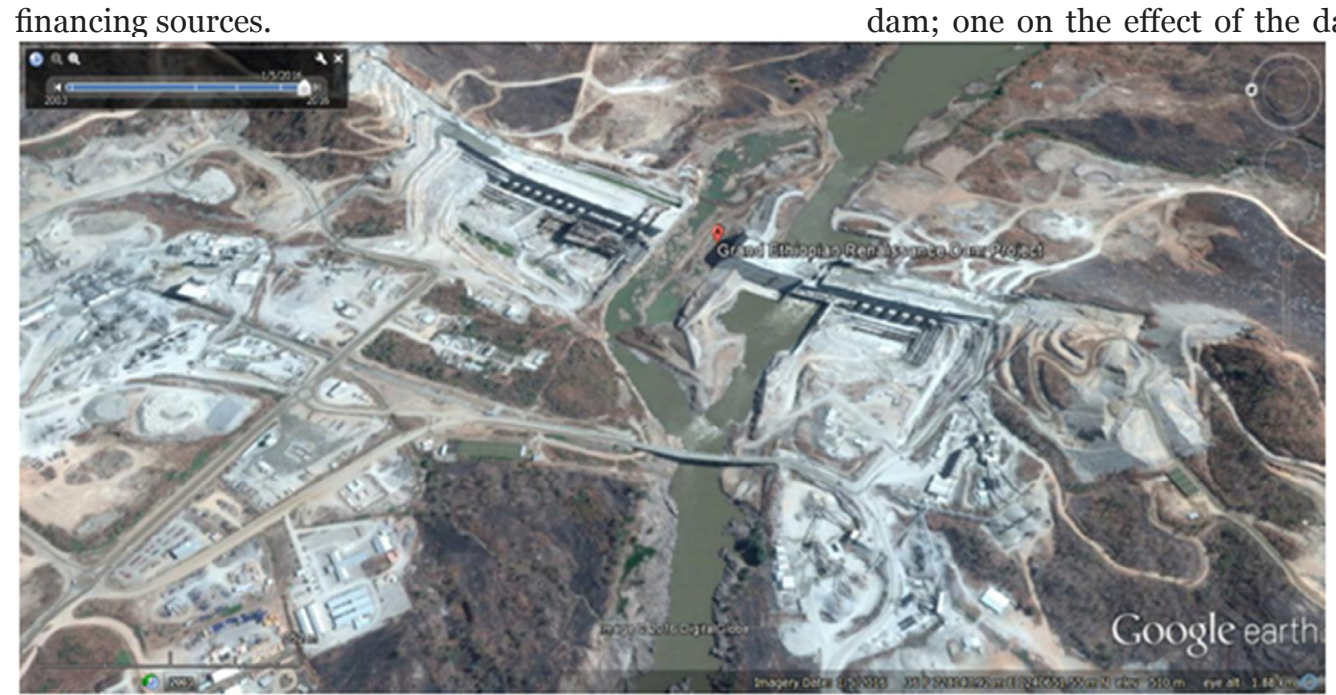

Figure 2: Google Images showing the under-construction GERD

\section{The Declaration of Principles}

The objections of the lower riparian states regarding the construction of the GERD project has decreased to some extent with the initiation of multilateral cooperation. These riparian countries of the North-Eastern Nile Arab Republic of Egypt, Federal Democratic Republic of Ethiopia and Republic of Sudan signed the Declaration on March 23, 2015 at Khartoum, Sudan. Ethiopia was successful in making this possible almost after four years since it started the construction of the GERD in 2011.

\section{Adoption of the Principles: From Conflict to Cooperation}

The shift of the North-East African states from water conflict to water cooperation was possible through the adoption of the 'Declaration of the Principles'. The Declaration valued the increasing need of Egypt, Ethiopia and Sudan for their transboundary (over border) water resources as mentioned in its Preamble. It has also realized the Nile as source of life and vital source for development of people of these states.

Since the Declaration is based on the essence of international water law and cooperation, the translation of the conflict over Nile into cooperation among these three riparian states was possible with its adoption. The declaration consists of following ten principles. These principles reflect the basic essence of the customary international law that has been established through UN Convention on Non-navigation Use of Water.

\section{How was it Adopted?}

It took over four years, since the construction, for Ethiopia to convince Egypt and Sudan to sign the Declaration of Principles on GERD and to recognize Ethiopia's right to construct the dam. Prior to the signing of Declaration, Ethiopia had already agreed with Egypt and Sudan to carry out further studies regarding the dam; one on the effect of the dam on the water quota of Sudan and Egypt, and the second one to examine the ecological, economic and social impact of the dam on Sudan and Egypt (MFA, 2016). The Declaration was adopted with calling for further technical studies on the effect of the project on the three riparian states. The three riparian states also agreed to form two committeesTripartite National Technical Committee and International Technical Experts Committee and cooperate on applying the committees' recommendations during the different stages of the project.

\section{Lessons for South Asia}

The Ganges basin is the home for about 655 million people (WB, 2014). With dense and increasing population depending on waters of the Ganges and high demands for irrigation water, the river basin is particularly vulnerable to increased water stress. Both the quality and quantity of regional water resources are under stress which is supplemented by increasing variability and scarcity of water, compounded by pressure on ground and surface water resources to meet intensified agricultural outputs and industrial needs (Varis, 2005). Attempts are made to compare the South Asian Lifeline- the Ganges River with the Lifeline of Northern Africa - the Nile in the following table and lessons to be learned in the subsequent subsections.

\section{Contested Terrain of International Water}

This dispute over Nile has lasted for over a century, but the riparian states with the goodwill have been successful in translating such conflicts into cooperation for the overall development of the basin states. More importantly, an upper riparian country Ethiopia has been able to establish its water right in contested terrain of water management where larger downstream 
riparian states of Sudan and Egypt have been historically dominating on Nile water. started with the colonial India which continued to the independent India. All the rivers originating from Nepal

\begin{tabular}{|c|c|c|c|}
\hline S. No. & Characteristics & Ganges River & Nile River \\
\hline 1. & \multicolumn{3}{|c|}{ Basin Characteristics } \\
\hline & Area (sq.km.) & $1,087,300$ & $\begin{array}{c}3,176,543 \text { (10 \% of } \\
\text { African Continent) }\end{array}$ \\
\hline & Countries & $\begin{array}{c}4 \text { (Bangladesh, } \\
\text { China, India and } \\
\text { Nepal) }\end{array}$ & 11 \\
\hline & Demography & 655 million5 & $\begin{array}{l}238 \text { million in } 2012 \\
\text { (54\% of popula- } \\
\text { tion of the basin } \\
\text { countries) }\end{array}$ \\
\hline \multirow[t]{3}{*}{2.} & \multicolumn{3}{|l|}{ Hydrology } \\
\hline & $\begin{array}{l}\text { Average Annual } \\
\text { Flow }\end{array}$ & $\begin{array}{l}380 \text { BCM (at } \\
\text { Farakka) }\end{array}$ & 84 BCM (at Aswan) \\
\hline & $\begin{array}{l}\text { Total Length of } \\
\text { River }\end{array}$ & 2525 km & 6695 km \\
\hline \multirow[t]{5}{*}{3.} & \multicolumn{3}{|l|}{ Water Uses } \\
\hline & Irrigation & $\begin{array}{c}90 \% \text { of total water } \\
\text { use }^{5}\end{array}$ & $\begin{array}{l}78 \% \text { of the peak } \\
\text { flow at Aswan }\end{array}$ \\
\hline & $\begin{array}{l}\text { Hydropower } \\
\text { Potential }\end{array}$ & $\begin{array}{c}40 \mathrm{GW}^{4} \text { in Nepal } \\
\text { alone }\end{array}$ & $28 \mathrm{GW}$ \\
\hline & $\begin{array}{l}\text { Annual Hydro- } \\
\text { power Genera- } \\
\text { tion }\end{array}$ & 12 terawatt hours & $\begin{array}{c}26 \% \text { of potential } \\
\text { capacity }\end{array}$ \\
\hline & $\begin{array}{l}\text { Navigation } \\
\text { Length }\end{array}$ & $631 \mathrm{~km}$ & 4149 km \\
\hline 4. & \multicolumn{3}{|c|}{ Basin Cooperation } \\
\hline 4.1 & \multicolumn{3}{|c|}{ Treaties and Agreements } \\
\hline & Bilateral & $\begin{array}{l}\text { Nepal and India } \\
\text { (Kosi Treaty-1954, } \\
\text { Gandak Agree- } \\
\text { ment-1959 and } \\
\text { Mahakali Trea- } \\
\text { ty-1996); Bangla- } \\
\text { desh and India } \\
\text { (Ganges Treaty, } \\
\text { 1996) }\end{array}$ & 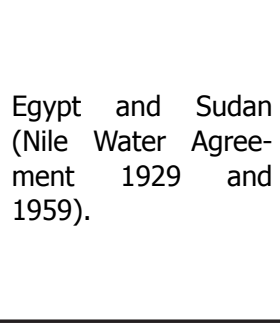 \\
\hline & Trilateral & None & $\begin{array}{l}\text { Ethiopia, Sudan and } \\
\text { Egypt (Declaration of } \\
\text { Principles on GERD- } \\
\text { 2015) }\end{array}$ \\
\hline & Multilateral & None & $\begin{array}{l}\text { Burundi, Ethiopia, } \\
\text { Kenya, Rwanda, Tan- } \\
\text { zania and Uganda } \\
\text { (Nile Cooperative } \\
\text { Framework Agree- } \\
\text { ment or Entebbe } \\
\text { Agreement- 2010) }\end{array}$ \\
\hline \multirow[t]{3}{*}{4.2} & \multicolumn{3}{|l|}{ Institutions } \\
\hline & Bilateral & many & 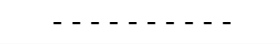 \\
\hline & Multilateral & none & Nile Basin Initiative \\
\hline
\end{tabular}

or originating in Tibet and passing through Nepal enter into India. Similarly, among the 54 rivers entering into Bangladesh from India, about 30 rivers face one or more upstream diversion basically in dry months creating socio-economic and environmental disasters (Afroz and Rahman, 2013). The bilateral agreements between Nepal and India on utilizing transboundary rivers are also not free of disputes and resulted into mistrust between the states (Upadhyay, 2012).

\section{Non Acceptance of Principle of Downstream Benefit Sharing}

The 1953 Agreement signed between Egypt and Britain (on behalf of Uganda) depicts the recognition of the downstream benefit sharing principle, even though there was not such principle established in that colonial era. However, the signing parties agreed on benefit sharing where Egypt agreed on compensating the loss and share the cost of construction of Owen falls dam for the benefit Egypt would reap from storing and regulating the water of Lake Victoria. If Uganda could receive share of the benefits due to water storage and regulation from the downstream state, why the states of the Ganges basin are, even today after more than six decades, not in a position to accept the Principle of downstream benefit sharing?

Much after the 1953 Agreement, the adoption of the 'Declaration of the Principles' of 2015 which mainly relied on realization of importance of regulated water in the downstream and understanding of water needs of both upstream and downstream states, was a major step in translating conflicts to cooperation in the Eastern Nile basin states. But in the case of South Asia, such realization has not been accepted as downstream states mainly, India has not yet been in a position to acknowledge such benefits. It is noteworthy to know that the acceptance of downstream benefit through regulated water by the GERD by downstream states of Egypt and Sudan was facilitated with the assessment of the World Bank. The Bank played a key role in assessing the downstream beenfits incurred by commissioning of GERD. Such assessment helped to increase the trust and cooperation in water development by the downstream states. But, in the case of Ganges basin, the same Bank was involved with the concept of avoiding such benefits (WB, 2014).

Table 2: Comparison between Ganges and Nile River

In case of Ganges, the dispute over the water

\section{Bilateralism in spite of Multilateralism}

India has persistently maintained that Ganga is an Indian river (IIDS, 1994). In this regard, Pun 
(2004) has rightly pointed out the fundamental reason behind India's aggressive bilateralism rather than multilateralism in Ganges water. The reason is the riparian right. India, being the middle riparian country between Bangladesh and Nepal, wants Nepal as an upper riparian state to protect India's existing uses of River waters. On the contrary, where India is itself the upper riparian state to Bangladesh, fails to commit the same which India wants from Nepal. This is why, despite many bilateral agreements on Ganges among the riparian states (Table 2), in practice, deep mistrust and chronic political tensions surround their implementation (Prasai and Surie, 2015). On the contrary, the three riparian states of eastern Nile opted for multilateralism forming multilateral committees and signing multilateral declaration.

\section{The Donor Driven Development}

For GERD, Ethiopia managed domestic sources for financing the project. On the contrary, most of the major water resources development projects are donor driven in Nepal, where the technology, manpower and funds are invested either from the international donor agencies or states. In recent years, some notable examples are observed where the funding is made available from the domestic sources. Such as the development of 22.1 MW Chilime Hydroelectric Project and associated underconstruction projects. Similarly, the funding for Upper Tamakoshi HEP (456 MW) has also been made available from within the country. In these cases, even the local people are the shareholders of the project. In the case of irrigation sector, the government has made provision of funds from domestic sources in few cases like Bagmati Irrigation Project, Sikta Irrigation Project or Bheri-Babai Diversion project.

But our tendency is still to search for international fund/loan providers. The major hydropower projects are either provided for international companies for development like Upper Karnali HEP (900 MW), Upper Marsyangdi HEP (60o MW), Arun III HEP (900 MW) or applied for loan/grant from the international funding agents like Tanahu HPP (140 MW), Upper Arun (335 MW), Dudhkoshi Storage Project (300 MW). The possibility of domestic fund investment for megaprojects in Nepal is still being underestimated.

\section{The Role of Giant Riparian}

The role of big (in terms of geographical or economic status) riparian is particularly important in attaining the cooperation among the riparian states. In the case of GERD, the bigger riparian country - Egypt as well as Sudan internalized the benefits due to upstream activities and helped moving from status quo to new era of water cooperation. In South Asia, despite efforts from the smaller riparian states-Nepal as well as Bangladesh, India has always been in a position of maintaining the status quo.

\section{The Data Secrecy}

For fostering regional cooperation in the basin and enhancing trust among riparian states, sharing of data and information is a must. The Declaration accepts sharing of data and information as an important aspect for cooperation and research on project of transboundary impact. Thus Egypt, Sudan and Ethiopia agreed on sharing the data required for the joint studies as stipulated in Principle VII of the Declaration.

Hydrological data and information are vital for proper utilization of water resources; on which design and management parameters depend on. In lack of such data, resources used and efforts made can be in vain. In order to enhance the regional cooperation and increase mutual trust among the riparians, sharing of such data is a requisite. Ironically, in South Asia, availability and access to hydro-related data are very limited. More importantly, information and data are difficult to obtain mostly in case of India, where hydrological data are still regarded as state's secret. Till date, there is no basinwide knowledge base and analytical framework that could be used by the riparian states to explore options and facilitate cooperative planning in the Ganges (WB, 2014). Unless information and data for research are not made available, the sustainable development and management of the Ganges seems to be difficult.

\section{Ethiopia's Lesson for Nepal}

A consistent challenge for Nepal is how to transform its "immense" water resources into desired economic prosperity. But the contest to decision makers and the hydro-intellects is not the technology awareness or use, rather to the way how decisions are made. So, the learning from Ethiopia's water resources development can be an eye-opening for Nepal. The Ethiopian case clearly shows that how an upper riparian country can establish its water right of fulfilling own water needs through development of a transboundary river in a contested terrain of water management. In fact, this is a case of a country which was less developed than others in the use of water, determines and asserts its right for an equitable use defying the historical right on the flow of water. As a matter of fact, the international law does recognize that an existing use is simply a factor and does not certainly hold a veto for the determinations of an equitable right. There is no prior right principle in the law.

In the context of transboundary waters, there are some comparable situations between Ethiopia and Nepal, which further simplifies us to learn lessons. As an upper riparian country, Ethiopia is the source of $86 \%$ of the Nile water while uses only $1 \%$ of that Nile water (Salman, 2015). The case is similar in the Ganges basin, where during the critical dry season, as much as $75 \%$ of Ganges flow at Farakka is contributed by Nepal's rivers so India essentially is interested in Nepal's water only and not hydropower (Pun, 2005). In addition, Ethiopia 
has recently gained political stability with the end of wars with Somalia and Eritrea and within Ethiopia. This stability has helped Ethiopia to indulge in economic development and start the journey of prosperity. The drafting and promulgation of New Constitution in Nepal is a major step towards peace and stability in Nepal. So, this opportunity must be taken by Nepal to initiate major water resources project for own use and for regional benefit. If economically weak, landlocked and upstream riparian country, Ethiopia can initiate such important project, then Nepal must also be in similar position to fulfill own demand without causing significant harm, rather benefiting the downstream countries. Decision makers of Nepal need to see Budhi Gandaki Storage Project from this perspective which has potential to bring regional benefits (Upadhyay and Gaudel, 2014).

The international law has acknowledged the principle of downstream benefit as well as rightly safeguarded the right of the riparian who are the late comers in the use of international water course. Yet, to realize this law Nepal has to show its determination and guts to do something for its benefit as appreciably as Ethiopia has done and shown to the whole world that even if the so called multilateral who claim themselves as the forerunners for big investment to the developing world countries are really not when it comes to the real help for countries like Ethiopia- country with less clout than Egypt in the international power clout.

\section{Conclusion and Way Forward}

In the context of complex transboundary water related challenges such as poor institutional capacity, poor water efficiency and increasing sectoral water demand, the water security of the Ganges Basin is at high risk. If South Asia wishes to have a prosperous future, then the regional cooperation on transboundary water is a must. Similar to the states of eastern Nile, all riparian states of the Ganges need to be urgently in a position to acknowledge the principle of downstream benefit in order to fostering the regional cooperation and overall development of the basin states. There is an urgent need to develop a Master Plan of downstream benefits of water resources development so as to be updated to synchronize bilateral and multilateral relation among the riparian states of the Ganges basin.

Surya Nath Upadhyay, LLM, from London University served the Government of Nepal for more than three decades and held various important and critical positions such as Secretary, Ministry of Water Resources; Chief Commissioner of the Commission for the Investigation of Abuse of Authority etc. During his career of civil servant, he remained involved in water resources for many years and preformed various roles - adviser, negotiator and decision maker. He has published several reports, articles and books, the recent one being a book entitled International Water courses Law and A perspective of Nepal-India Cooperation. Presently, he is associated with JVS, a civil society organization for water resources development. He is also a member of Eminent Persons' Group (EPG).

E-mail: mail@jvs.org.np or suryanathupadhyay@ gmail.com

Prakash Gaudel, joined Nepal Electricity Authority (NEA) in 2011. He is currently working as an Assistant ManageratEnvironment and SocialStudies Department of NEA. He holds M.Sc. degree in Interdisciplinary Water Resources Management from Nepal Engineering College (Pokhara University) and M.Sc. in Environment Science from Kurukshetra University, India.

Corresponding E-mail: prakgaudel@gmail.com

\section{Footnotes}

1. These riparian countries are Burundi, Congo, Egypt, Eritrea, Ethiopia, Kenya, South Sudan, Sudan, Tanzania, Rwanda and Uganda.

2. Sudan attained its independence from Britain in 1956.

3. The ten principles of the declaration are : I- Principle of Cooperation, II- Principle of Development, Regional Integration and Sustainability, III- Principle Not to Cause Significant Harm, IV-Principle of Equitable and Reasonable Utilization, V- Principle to Cooperate on the First Filling and Operation of the Dam, VI-Principle of Confidence Building, VII- Principle of Exchange of Information and Data, VIII-Principle of Dam Safety, IX-Principle of Sovereignty and Territorial Integrity and X-Principle of Peaceful Settlement of Disputes.

4. IIDS 2000. The average annual flow in the Ganges as recorded at Farakka (1948-1973) is around 380 BCM and as recorded at Hardinge Bridge in Bangladesh is around $383 \mathrm{BCM}$.

5. WB 2014.

6. There are a number of bilateral institutions established between Nepal and India including Joint Commission on Water Resources (JCWR), Joint Commission on Koshi and Gandak Project (JCKGP), Joint Standing Technical Committee (JSTC) and Joint Committee on Inundation and Flood Management (JCIFM).

7. Project Development Agreement (PDA) has been signed with the Indian Company GMR for $900 \mathrm{MW}$ Upper Karnali HEP, whereas PDA of 900 MW Arun III HEP has been signed with another Indian company Satluj. The PDA of 600 MW Upper Marsyangdi HEP is to be sigend with GMR.

8. JICA/ADB are taking stake in Tanahu HEP, World Bank in $300 \mathrm{MW}$ Upper Arun, and ADB in $300 \mathrm{MW}$ Dudhkoshi Storage Project.

\section{References}

Afroz, R. \& Rahman, M. A. (2013) Transboundary River Water for Ganges and Teesta Rivers in Bangladesh: An Assessment. In: Global Science and Technology Journal Vol. 1, No. 1, July Issue, pp.100-111.

Deng, B. K. (2007) Cooperation between Egypt and Sudan over the Nile River Waters: The Challenges of Duality. 
In: African Sociological Review, Vol. 11(1), pp.38-62.

IIDS (1994) Converting Water into Wealth-Regional Co-operation in Harnessing the Eastern Himalayan Rivers. (Eds. Q.K. Ahmad, B.G. Verghese, R.R. Iyer, B.B. Pradhan and S.K. Malla) Institute for Integrated Development Studies, Kathmandu.

IPoE (2013) Final Report of International Panel of Experts on Grand Ethiopian Renaissance Dam Project. Adis Ababa, Ethiopia. Retrieved from: http://www.scidev. net/filemanager/root/site assets/docs/international panel_of_experts_for_ethiopian_renaissance_damfinal_report.pdf

McKenzie, S.O. (2012) Egypt's Choice: From Nile Basin Treaty to the Cooperative Framework Agreement, an International Legal Analysis. In: Transnational Law and Contemporary Problems, Vol. 21, pp. 571-599.

MFA (2016) Ethiopia committed to the implementation of the Declaration of Principles. Ministry of Foreign affairs, Federal Democratic Republic of Ethiopia. Retrieved from: http://www.mfa.gov.et/-/ethiopiacommitted-to-the-implementation-of-the-declarationof-principles

Mohamed, Y.A. \& Loulseged, M. (2008) The Nile Basin Water Resources: Overview of Key Research Questions Pertinent to the Nile Basin Initiative. Colombo, Sri Lanka: International Water Management Institute. 34p. (IWMI Working Paper 127)

Mulat, A.G. \& Moges, S.A. (2014). Assessment of the Impact of the Grand Ethiopian Renaissance Dam on the Performance of the High Aswan Dam. In: Journal of Water Resource and Protection, 6, 583-598. Retrieved from: http://dx.doi.org/10.4236/jwarp.2014.66057

Okoth-Owiro, A. (2004) The Nile Treaty -State Succession and International Treaty Commitments: A Case Study of the Nile Water Treaties. Konrad Adenauer Foundation, Nairobi, Kenya.

Prasai S. \& Surie, M.D (2015). Water and Climate Data in the Ganges Basin: Assessing Access to Information Regimes and Implications for Cooperation the Transboundary Rivers. In: Water Alternatives, Vol. 8, Issue 2; pp. 20-35.

Pun, S.B. (2005) Nepal's Hydropower Export in the Context of India's River Linking Project. In: Proceedings of 6th International Conference on Development of Hydropower- A major Source of Renewable Energy.
Organized by International Association of Electricity Generation, Transmission and Distribution (AfroAsian Region), Nepal Electricity Authority and Central Board of Irrigation and Power- India, June 7-9, Kathmandu. pp. III110-III122.

Pun, S.B. (2004) Overview: Conflicts over the Ganga? In: Disputes over the Ganga: A Look at Potential Waterrelated Conflicts in South Asia (Eds. B. Subba and K. Pradhan) Panos Institute South Asia Kathmandu, Nepal. pp. 2-21.

Sadoff, C.W. \& Grey, D. (2002) Beyond the River: The Benefits of Cooperation on International Rivers. Water Policy 4, Elsevier Science Ltd., pp. 389-403.

Salman, S.M.A. (2015) How and Why has the Ethiopian Strategy on the Renaissance Dam Succeeded? In: Sudan Vision News Daily (March 30, 2015). Retrieved from: http://www.sudanvisiondaily.com/

Salman, S.M.A. (2013) The Nile Basin Cooperative Framework Agreement: A Peacefully Unfolding of African Spring? In: Water International, Vol. 38(1), pp.17-29.

Schadomsky, L. (2013) Water- Egypt and Sudan Argue over Dam Project. Retrieved from http://www. dw.com/en/egypt-and-ethiopia-argue-over-damproject/a-16880722

Upadhyay, S.N. (2012) International Watercourses Law and a Perspective on Nepal-India Cooperation. Ekata books, Kathmandu, Nepal.

Upadhyay, S.N. \& Gaudel, P. (2014) Cross-border Downstream Benefit Sharing in Reservoir Type Hydropower Projects- Case of Budhi Gandaki Storage Project in Nepal. In: Hydro Nepal-Journal of Water, Energy and Environment, Issue No. 14 (January, 2014), Media for Energy Nepal and JVS/GWP Nepal, Kathmandu, pp. 59-64.

Varis, O. (2005) Externalities of Integrated Water Resource Management in South and Southeast Asia. In: Integrated Water Resources Management in South and South-East Asia (eds. A. Biswas et al). Oxford University Press, New Delhi and Oxford. pp. 1-38.

WB (2014) Ganges Strategic Basin Assessment: A Discussion of Regional Opportunities and Risks. World Bank South Asia Regional Report. 